Teaching \& Learning (2012) 7(2), i-vii

\title{
Editorial: Teaching \& Learning Special Issue on Equity, and Engagement
}

\author{
Teaching \& Learning
}

Guest Editors:

ARMSTRONG, D. E., RATKOVIC, S., \& HANDS, C.

Brock University

As individuals and communities become more informed and interconnected at the local and global levels, awareness of human rights as they relate to individuals, organizations, and societal institutions have been on the rise. In the field of education, issues of equity have consistently been linked to teaching and learning practices, with researchers identifying gaps in student achievement (Ryan, 2012), disengagement (McMahon \& Armstrong, 2010), dropout (Dei, 2008), and incarceration (Solomon \& Palmer, 2006), that reproduce and perpetuate social injustice. It is therefore not surprising that a number of community, district, and school programs, government policies, and university research studies have been developed in Canada, and abroad, in order to address and redress these pervasive inequities. For the most part, these initiatives highlight the importance of creating equitable environments that engage individuals and communities irrespective of their backgrounds (e.g., ancestry, ability, income, identity, race, and religion). While espousing values such as diversity, inclusion, and social justice, the interventions often link these ideals to a variety of contested goals such as student success, societal cohesiveness, economic prosperity, and consumer satisfaction. For example, the Ontario Ministry of Education's (OME) Equity and Inclusive Education Strategy (2009) identifies equity as integral to achieving its three core priorities of "high levels of student achievement", "reduced gaps in student achievement" and "increased public confidence in publicly funded education" (p. 5). In addition to improving outcomes for students at risk of disengaging from or dropping out of school, this strategy states that:

all partners must work to identify and remove barriers and must actively seek to create the conditions needed for student success. In an increasingly diverse Ontario, that means ensuring that all of our students are engaged, included, and respected, and that they see themselves reflected in their learning environment. 
Unfortunately, research in Ontario and abroad shows that achieving equity remains a complex and difficult endeavor, even for individuals who are committed to creating and sustaining inclusive schools (Dei, 2003; McMahon \& Armstrong, 2011; Ryan, 2012; Shields, 2004; Solomon, 2002; Theoharis, 2010). Educators who do equity and social justice work encounter formidable social and political obstacles that are related to unresponsive attitudes and resistance from supervisors and peers, and a lack of training, resources, and support (Armstrong, Tuters, \& Carrier 2012; Ryan, 2012; Shields, 2004). Consequently, in order to effect positive change and maintain momentum, educators have to develop a varied repertoire of skills, which includes acquiring and mobilizing knowledge, creating networks and allies, and accessing needed resources (Armstrong et al., 2012; Ryan, 2012).

\section{Background to the Equity, Engagement, Teaching and Learning Special Issue}

In order to aid educators in these endeavors, three faculties of education (Brock University, Western University, and OISE/University of Toronto) and their local school boards in the Niagara, Peel, and Thames Valley districts, joined forces to develop a series of conferences and workshops across Ontario, which were supported by the Knowledge Network for Applied Education Research (KNAER), as well as community and school district partners.

In February 2012, Brock University’s Faculty of Education Equity, Engagement, Teaching and Learning Committee organized and presented a one-day conference designed to bring together and engage faculty, Ministry of Education personnel, community members, students, school board representatives, and educators, in discussions around equity, engagement, teaching and learning. Another important objective of this conference was to initiate the development of supportive and sustainable social justice networks in the Niagara region and beyond. The conference was funded by a KNAER, Ontario Ministry of Education grant, as well as sponsored by Brock University's Faculty of Education, the Faculty Association (BUFA) Social Justice Committee, the Office of Human Rights and Equity Services, and the Social Justice and Equity Studies Program. Over 130 participants from Brock University, eight school boards, seven community organizations, three governmental institutions, and Niagara College, participated in this event. What transpired at the conference was much fruitful dialogue on various issues of inclusion and equity, opportunities for knowledge mobilization, and the sharing of diverse perspectives. In particular, participants shared information regarding creating and 
instituting procedures and processes that respect individual and community diversity, redress conditions of disadvantage, and support the meaningful access, participation, and success of all groups and individuals. Participants also raised issues related to: greater inclusion of diverse student and community voices; a focus on globalization, equity studies and intersectionality; engagement in applied education research; the sharing of effective and practical strategies; and the development of specific short-term and long-term action plans.

\section{Continued Conversations}

This special issue of Teaching \& Learning emerged from our desire to share and sustain these conversations related to equity, engagement, teaching and learning. The resulting two series in Volume 7, mirror the diversity of topics that were raised during the conference. The six articles in Volume 7, Issue 2 of this special edition, encourage us to take a closer look at issues of inclusion and equity of access and outcome, as they relate to students', educators', and parents' ability to access not only the physical buildings, but also to successfully navigate and transform hidden structural elements, regardless of race, social position, financial means, and physical and cognitive abilities.

The first six articles in this special issue of Teaching \& Learning move the discussion from visible to less visible barriers to access and engagement in education. The first article by Katina Pollock (pp. 1-15), discusses broader issues of inclusion and social justice as they relate to access to, and engagement of, marginalized communities in public educational systems. In addition to outlining multiple issues of access, this article reframes student engagement in ways that challenge educators to rethink how they currently understand student engagement, and it outlines strategies for promoting student and community access and engagement in education. The author warns social justice educators that "In a socially just and equity-minded world it is not enough to build a school, furnish it with resources and teachers, and provide guidance through curriculum policies...Awareness of the interplay between issues of access to education and student engagement need to be considered when responding to students' needs" (Pollock, $p$. 12).

Inclusive and exclusive school practices impact students and the extended community, as well as practicing and potential teachers. The second article by Christine Rougoor (pp.16-27), highlights equity issues from a teacher candidate's point of view. Using a narrative approach, she 
describes the physical and attitudinal challenges she faced as student teacher with a physical disability, and the practices that facilitated and hindered her ability to succeed in such a limiting environment. Her experiences highlight the importance of physical, architectural, and attitudinal inclusion, and the roles and responsibilities of school leaders to facilitate inclusive environments for all. More specifically, Rougoor highlights the need for school principals to be knowledgeable about disability issues; to recognize and eliminate physical barriers to access; to use preventative instead of reactive strategies; and to create inclusive school environments for staff and students.

Educational administrators' legal and moral obligation to create equitable and ethical schools is highlighted in the third article by Katlyn Davis and Denise Armstrong (pp. 28-40). This article emphasizes the critical role that school leaders have in engaging diverse communities and promoting school-level inclusive practices that ensure access and success for racialized students. They discuss fundamental concepts school leaders should know about racialized equity, as well as proactive approaches and research informed strategies they can employ. These include understanding fundamental concepts of race and racism; adopting multiple approaches such as social justice, critical multiculturalism, and antiracism; employing equity audits; and engaging in authentic community participation on a regular basis.

A number of educational administrators and teachers recognize the importance of parent engagement to student academic success, and have taken steps to include parents who have been traditionally marginalized. The fourth article by Catherine Hands (pp. 41-62), further highlights how educators can work with communities to strengthen parent engagement in their children's education. She describes how five school board-level parent engagement projects supported parents who faced barriers to engagement, such as poverty and cultural diversity issues. Hands highlights a number of specific parent engagement strategies used by the participating school boards such as covering the cost of programs involving parents, providing childcare or hosting family friendly events, and limiting or eliminating transportation costs to events. Furthermore, she urges provincial education departments and ministries to support educators in developing and sustaining "inclusive initiatives in which families become knowledgeable co-constructors of their children's education" (Hands, p. 41).

The fifth article by Brenda McMahon, John Smyth, Geoff Munns, and David Zyngier (pp. 63-78), illustrates how researchers and practitioners can engage students through participatory and democratic processes. This article foregrounds three student engagement 
initiatives that were successfully implemented in Australia and Canada. In order to counteract the negative impacts of exclusionary reforms and schooling practices that marginalized visible minority and low-income students, these programs implemented approaches and strategies that respected students' strengths and honoured their voices. The strategies described in this paper facilitate "student engagement that is transformative, and is inconsistent with schooling, where educators use deficit approaches to students, follow curricular documents as though they were scripts instead of guides, and accept de-professionalization" (McMahon, Smyth, Munns, \& Zyngier, p. 74).

The last article highlights educators' strategies to include students who learn differently. Vera Woloshyn, Nancy Taber, and Laura Lane (pp. 79-96), detail their research on girls' literacy and learning disabilities, and provide educators with an effective strategy for supporting and engaging students with reading difficulties. Their findings illustrate how four pre-adolescent girls engaged with, and critiqued text, in terms of societal issues related to gender and selfempowerment. As this book club was an after-school activity with a small group of participants, the authors "were able to engage with the girls and the text in ways that may be challenging for educators in school settings" (Woloshyn, Taber \& Lane, p. 93). The girls' responses to the texts underscore the importance of holding ongoing, structured conversations, and engaging youth in a societal gendered critique.

\section{Equity and Social Justice Work in Education}

Our conference dialogues and the resulting special issue were envisioned as starting point for individual and community reflection on theory, practice and research. As you consider the stories and the theoretical and empirical research contained within this special issue, we encourage you to reflect on your beliefs and practices and to consider questions such as:

- How are our current definitions of equity, engagement, teaching and learning interpreted?

- What are the goals and purposes of equity, engagement, teaching and learning?

- Who benefits and who is disadvantaged by our definitions, goals and purposes?

- What do we mean by access? How do we move beyond access to success?

- How do we deepen discourses in educational institutions?

- How do we situate ourselves as critical actors and responsible educators? 
The last question is particularly important since it speaks to our agency as caring educators. Ultimately, the onus is upon us, as individuals and as part of a community, to make the changes necessary to fully understand and embrace equity and social justice, in education, and in our personal and professional lives. While recognizing equity and social justice work in education as a lonely and challenging endeavor, the authors of the articles included in this volume emphasize the importance of professional knowledge, personal commitment, and social justice networks, in building inclusive schools and practices. These social justice educators remind us, in their unique and inspiring ways, of the following West African proverb:

\section{If you think you are too small to make a difference, you have never been}

in the dark with a mosquito.

Denise E. Armstrong is an Associate Professor, Administration and Leadership, in the Faculty of Education at Brock University, and she has worked in a variety of academic and administrative roles in K-20 institutions in Canada and the Caribbean. Her writing and research focus on ethical leadership, social justice, and antiracist pedagogy and she is the author of "Administrative Passages: Navigating the Transition from Teacher to Assistant Principal" and co-author of "Inclusion in Urban Educational Environments: Addressing Issues of Diversity, Equity and Social Justice".

Snežana Ratković is a science teacher from the former Yugoslavia who immigrated to Canada in 1998, after the civil war in the country. Presently, she works as research officer for the Faculty of Education at Brock University. Snežana is a doctoral candidate in educational studies and explores the experiences, identities and transitions of refugee female teachers from the former Yugoslavia who immigrated to Ontario and Quebec between 1991 and 2001. Snežana's scholarship is rooted in social, cultural, and political contexts of education with an emphasis on immigration and settlement, teacher identity, teacher education, research ethics, and social justice studies. She has published in The Reading Professor, Forum Qualitative Sozialforschung / Forum: Qualitative Social Research, South African Journal of Higher Education, Power and Education, Educational Action Research Journal, and Studies in Higher Education.

Catherine Hands is currently appointed as an Assistant Professor at Brock University, where she teaches in the Administration and Leadership in Education program in the Faculty of Education. As a researcher, teacher and consultant, Catherine has worked with Ontario school boards, the Elementary Teachers' Federation of Ontario, and the Ontario Ministry of Education's Parent Engagement Office. Catherine's research interests stem from her experiences in the classroom, as well as her work with school leaders and teachers, and include school-community relations, family involvement in schooling, schools as communities, educational leadership, values and ethics in education, social justice, professional learning communities, and educational 
reform. She maintains an active research agenda in these areas, and has presented and published her work regionally, nationally and internationally.

\section{References}

Armstrong, D. E., Tuters, S., \& Carrier, N. (2012). The micropolitical process of social justice leadership: When educators' perspectives and actions conflict. Paper presented at the Annual Meeting of the American Educational Research Association, April 13-17, Vancouver, British Columbia.

Dei, G. (2008). Schooling as community: Race, schooling, and the education of African youth. Journal of Black Studies, 38(3), 346-366.

McMahon, B., \& Armstrong, D. (2010). Unraveling the knots and strengthening the ties: Countering democratic racism. International Journal of Urban Educational Leadership, 4(1), 160-172.

Ontario Ministry of Education. (2009). Ontario's Equity and Inclusive Education Strategy. Toronto, ON: Queen's Printer for Ontario. Retrieved from http://www.edu.gov.on.ca/eng/policyfunding/equity.pdf

Ryan, J. (2012). Struggling for inclusion: Educational leadership in a neoliberal world. Charlotte, NC: Information Age Publishing.

Shields, C. (2004). Dialogic leadership for social justice: Overcoming pathologies of silence. Educational Administration Quarterly, 40, 109-132: DOI: 10.1177/0013161X03258963

Solomon, R. (2002). School leaders and antiracism: Overcoming pedagogical and political obstacles. Journal of School Leadership, 2, 174-197.

Solomon, R., \& Palmer, H. (2006). Black boys through the school prison pipeline: When "racial profiling" and "zero tolerance" collide. In D. E. Armstrong and B. J. McMahon (Eds.), Inclusion in urban educational environments: Addressing issues of diversity (pp.191-212). Greenwich, CT: Information Age Publishing.

Theoharis, G. (2010). Disrupting injustice: Principals narrate the strategies they use to improve their schools and advance social justice. Teachers College Record, 112(1), 331-373. 